\title{
Influence of Lactoferrin on Iron Absorption from Human Milk in Infants
}

\author{
LENA DAVIDSSON, PETER KASTENMAYER, MICHELLE YUEN, BO LÖNNERDAL, AND \\ RICHARD F. HURRELL
}

Nestle Research Center, CH-1000 Lausanne 26, Switzerland [L.D., P.K., R.F.H.] and

Department of Nutrition, University of California, Davis, California 95616 [M.Y., B.L.]

\begin{abstract}
Lactoferrin (Lf) is a major iron (Fe)-binding protein in human milk and has been proposed to facilitate Fe absorption. The potential effect of $L$ f on Fe absorption was investigated by measuring Fe absorption in infants fed breast milk (with its native content of $L f$ ) and the same milk from which Lf had been removed $(>97 \%)$ by treatment with heparin-Sepharose. Eight breast-fed infants (2$10 \mathrm{mo}$; mean age $5 \mathrm{mo}$ ) were fed 700 to $1000 \mathrm{~g}$ of each milk in a randomized, cross-over design with each child acting as his/her own control. The milk was labeled with $8.6 \mu \mathrm{mol}(0.5 \mathrm{mg})$ of ${ }^{58} \mathrm{Fe}$ and $\mathrm{Fe}$ absorption was measured by quantifying the incorporation of the isotope into red blood cells $14 \mathrm{~d}$ after intake using thermal ionization mass spectrometry. Fractional Fe absorption was significantly lower $(p<0.05)$ from breast milk than from Lf-free breast milk. The geometric mean (range) was $11.8 \%(3.4-37.4 \%)$ for breast milk and $19.8 \%(8.4-72.8 \%)$ for Lf-free breast milk. These results do not support a direct role for $\mathbf{L f}$ in the enhancement of $\mathrm{Fe}$ absorption from human milk at this age. In addition, Fe absorption (11.8\%) from human milk fed over several feeds was lower than that previously reported for single feed studies. (Pediatr Res 35: 117-124, 1994)
\end{abstract}

\section{Abbreviations}

Fe, iron

Lf, lactoferrin

SDS-PAGGE, sodium dodecyl sulfate-gradient polyacrylamide electrophoresis

GFAAS, graphite furnace atomic absorption spectrometry FPLC, fast liquid protein chromatography

The concentration of $\mathrm{Fe}$ in human milk is low and decreases during the course of lactation $(1,2)$, but its bioavailability has been assumed to be high because exclusively breast-fed infants do not show signs of Fe deficiency during the first 6 mo of life $(3,4)$. Fractional Fe absorption from human milk has been reported to be significantly higher than from cow's milk and infant formulas when estimated in infants by calculating changes in total body $\mathrm{Fe}(5,6)$ or when measured with a radioisotope technique (7). A difference in $\mathrm{Fe}$ absorption between human and cow's milk has also been shown in studies of adult subjects (810). This difference in Fe bioavailability from human and cow's milk has been discussed in relation to the presence of either inhibitory factors in cow's milk and infant formulas, or to the

Received March 18, 1993; accepted July 27, 1993.

Correspondence: Lena Davidsson, Nestlé Research Center, P.O. Box 44, CH1000 Lausanne 26, Switzerland.

Supported in part by Grant DK-43850 from NICHD. presence of substances enhancing Fe absorption from human milk.

Human milk differs from cow's milk in several respects, among them the total content of protein, the ratio of casein/whey, as well as the nature of the individual casein and whey proteins. Adapted infant formulas have a protein concentration much closer to human milk and a similar casein/whey ratio, but differ in the levels of individual proteins. For example, $\beta$-lactoglobulin represents almost half the total whey protein in infant formula, but is absent in human milk. On the other hand, the concentration of $\alpha$-lactalbumin is higher in infant formula than in human milk and Lf, which is one of the major whey proteins in human milk, is present in very low amounts in infant formula. Furthermore, more than $50 \%$ of the total casein in formula is in the form of $\alpha$-s1 and $\alpha$-s 2 caseins, whereas human milk contains almost exclusively $\beta$-casein (11). These differences could be of importance in terms of $\mathrm{Fe}$ absorption because $\alpha$-caseins are more phosphorylated than $\beta$-caseins and an inhibitory effect of bovine casein on Fe absorption has been demonstrated in human adults $(11,12)$. The much higher content of calcium in cow's milk than in human milk has also recently been proposed as largely the cause for the difference in Fe absorption (10).

It has been suggested that $\mathrm{Lf}$ is a possible promoter for $\mathrm{Fe}$ absorption from breast milk (2). Lf is one of the most abundant whey proteins in human milk, whereas concentration of $\mathrm{Lf}$ in mature cow's milk is much lower and, thus, virtually absent in infant formula. This protein has been proposed as a delivery system by which $\mathrm{Fe}$ can be absorbed from human milk because $\mathrm{Lf}$ is the major $\mathrm{Fe}$ binding protein present. Lf, like transferrin, reversibly binds two ferric ions but the affinity constant is greater for $\mathrm{Lf}$ than that for transferrin and the Lf-Fe complex has a considerably stronger dissociation constant requiring a lower $\mathrm{pH}$ $(<3)$ to release $\mathrm{Fe}(13)$. The function of $\mathrm{Lf}$ in $\mathrm{Fe}$ absorption necessitates the survival of the protein during passage through the gastrointestinal tract, which has been verified by the finding of intact $L f$ in feces from breast-fed infants $(14,15)$. Studies of Lf isolated from fecal material collected from newborn infants have shown that $\mathrm{Lf}$ with bound Fe survived the passage through the gastrointestinal tract better than Fe-free (apo)-Lf (16). Furthermore, receptors binding Lf specifically for each species have been identified in humans $(17,18)$, rhesus monkeys (19), mice (20), and suckling pigs (21). It has also been demonstrated that even after partial digestion of $\mathrm{Lf}$, i.e. cleavage into fragments, the half-molecule still retains enough structural integrity to interact with the receptor albeit with lower affinity than intact $\mathrm{Lf}(22)$.

Although the biological role of $L f$ has been debated for a long time, no conclusive data have been reported to clarify the importance of this protein in Fe absorption from human milk. Studies in piglets (23), weanling mice (24), and infant rhesus monkeys (25) showed that the bioavailability of Fe bound to Lf was no better than that of inorganic Fe. Earlier human studies regarding the role of $\mathrm{Lf}$ on $\mathrm{Fe}$ absorption in infants have used bovine Lf $(26-28)$ or have conducted the studies in adult subjects 
(9). The results from these studies are difficult to interpret in relation to breast-fed human infants.

The present study was designed to investigate the influence of $\mathrm{Lf}$ on Fe absorption from human milk in infants. Fe absorption was measured from human milk in breast-fed infants 1 ) with the native level of Lf present and 2) after removal of $>97 \%$ of the Lf. The study had a randomized, cross-over design and $\mathrm{Fe}$ absorption was measured by stable isotope technique, using ${ }^{58} \mathrm{Fe}$ as a label, with $\mathrm{Fe}$ absorption measured by analysis of the incorporation of ${ }^{58} \mathrm{Fe}$ into red blood cells $14 \mathrm{~d}$ after administration.

\section{MATERIALS AND METHODS}

Subjects. Mothers with healthy term infants were recruited via advertisements in local papers or via pediatricians in the area. The parents were fully informed about the aims and procedures of the study and consent forms were signed by each mother before enrollment in the study. All infants were breast-fed although the older infants were given small portions of solid foods (cereals, fruits, etc.). However, during the Fe absorption study no other foods or fluids than labeled breast milk were given. Four girls and four boys were recruited for the study. Mean birth weight was $3576 \mathrm{~g}$ (range, 3062-3856 g). Mean age at enrollment in the study was $5 \mathrm{mo}$ (range, 2-10 mo).

The protocol was approved by the Human Subjects Committee at the University of California at Davis.

Collection of Breast Milk. Breast milk was expressed by using either a manual (Comfort Plus, Kaneson breast pump, Omron Marshall Products Inc., Lincolnshire, IL), an electric breast pump (Gerber Products Company, Fremont, MI) or a Medela breast pump (Medela Inc., Crystal Lake, IL). All parts of the pumps being exposed to the breast milk were washed with hot water and a mild detergent followed by rinsing with ultra pure water (17.5 M $\Omega$; Sybron, Barnstead, MA) between usage. Expressed milk was stored at $-20^{\circ} \mathrm{C}$ in sterile disposable bottles (Playtex Family Products Corp., Dover, DE) until the requested total volume of approximately $2 \mathrm{~L}$ of milk was obtained. Some mothers were not able to produce this amount of milk and a smaller quantity was therefore administered to their infants. The volume of labeled milk was, however, kept constant at the two administrations for each infant. The total time period for collecting the milk was at most 3 wk and all infants were nursed during this time.

Manual and small electrical breast pumps as well as sterile bottles, ultrapure water, and detergent were provided during the study.

Preparation of Lf-free Breast Milk. All milk expressed by each mother was thawed and pooled in a sterile plastic container. The total weight was registered and the milk was separated into two equal parts. One part was labeled with ${ }^{58} \mathrm{Fe}$ without any further modifications ("breast milk"), whereas the other part was treated with heparin-Sepharose gel to remove Lf ("Lf-free breast milk") (Fig. 1).

Lf-free breast milk was prepared by addition of heparin-Sepharose CL-6B gel (Pharmacia LKB Biotechnology, Piscataway, $\mathrm{NJ})$. Aliquots $(200 \mathrm{~g})$ of milk were centrifuged in $250 \mathrm{~mL}$ previously autoclaved centrifuge bottles at $4^{\circ} \mathrm{C}$ and $4068 \times g$ for 30 min using a Sorvall GSA rotor (Sorvall RC-5B, DuPont Instruments, Wilmington, DE). Fat was removed with a plastic spatula, weighed, and kept frozen. To each defatted milk fraction remaining in the centrifuge bottles, $10 \mathrm{~g}$ (freeze-dried weight) heparin-Sepharose were added. Each 10-g aliquot of gel had been previously washed according to the manufacturer's instructions in $200 \mathrm{~mL}$ of ultrapure water per gram of freeze-dried gel. The washed gel was allowed to swell in ultrapure water for approximately $15 \mathrm{~min}$ before addition to the defatted milk fraction. The defatted milk/gel mixture was left at $4^{\circ} \mathrm{C}$ under gentle shaking conditions overnight. The gel was then removed by centrifugation $\left(366 \times g, 4^{\circ} \mathrm{C}\right.$ for $15 \mathrm{~min}$ ) followed by filtration through

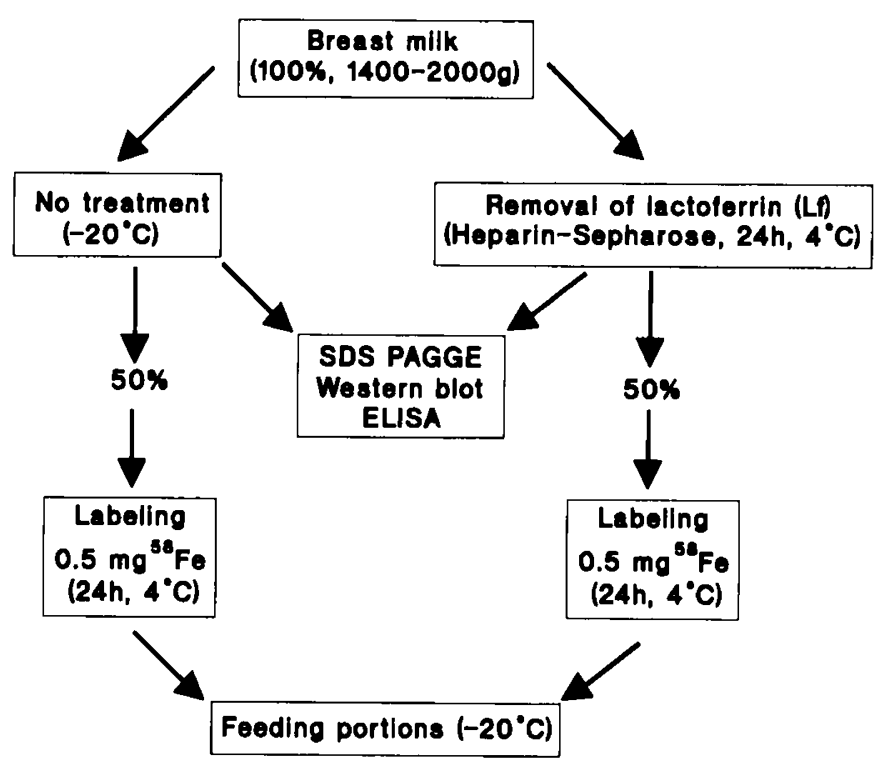

Fig. 1. Preparation of feeding portions of breast milk and Lf-free breast milk, respectively.

four layers of cheese cloth into a preweighed sterile plastic bottle. The total weight of defatted milk was registered; a very small amount (3-4\% of total weight) was lost during the treatment.

The completeness of the $\mathrm{Lf}$ removal from the milk was controlled immediately after the treatment by SDS-PAGGE (10$20 \%$ plates, Daiichi Pure Chemicals Co. Ltd., Tokyo, Japan) followed by Western blotting. Proteins were transferred to nitrocellulose paper (pore size $0.2 \mu \mathrm{m}$, Schleicher \& Schuell, Keene, $\mathrm{NH}$ ) in $0.02 \mathrm{M}$ TrisBase/0.15 M glycine buffer ( $\mathrm{pH} 8.3$ ) by using a transfer electrophoresis unit (Hoefer Scientific Instruments, San Francisco, CA) at $200 \mathrm{~mA}$. Rabbit anti-human Lf (Dako, Copenhagen, Denmark) was used as the primary antibody and goat anti-rabbit IgG alkaline phosphate conjugate (Bethesda Research Laboratories, Gaithersburg, MD) as the secondary antibody. Untreated breast milk from the same mother was used as the reference. The concentration of $\mathrm{Lf}$ in the milk samples was measured quantitatively by ELISA. Rabbit anti-human Lf (Dako) was used as the primary antibody and goat-anti rabbit IgG alkaline phosphate conjugate (Bethesda Research Laboratories) as the secondary antibody for both Western blot and ELISA.

Lf was removed from the heparin-Sepharose by washing with 4 volumes of $2 \mathrm{M} \mathrm{NaCl}$. Thereafter, the gel was washed with 5 vol ultrapure water, vacuum-filtered, and kept stored at $4^{\circ} \mathrm{C}$ in $20 \%$ ethanol. Before being reused, the gel was again washed with 5 vol ultrapure water and autoclaved at $100^{\circ} \mathrm{C}$ for $10 \mathrm{~min}$ in 5 vol of water. Each gel was recycled two to three times.

Total protein content of milk samples was determined colorimetrically by the BioRad method (BioRad Protein Assay, BioRad Laboratories, Richmond, CA). The Fe content of breast milk and Lf-free breast milk was measured on freeze-dried aliquots by GFAAS, using model 975 AAS (Varian Techtron, Mulgrave, Australia) equipped with a GTA-95 graphite furnace and an autosampler. Milk samples were wet ashed in a microwave digestion system (MDS-81D, CEM corporation, Matthews, NC) using lined digestion vessels (maximum operating pressure $1380 \mathrm{kPa}$ ). A two-step digestion procedure was used. Approximately $200 \mathrm{mg}$ of sample were heated with $5 \mathrm{~mL}$ of concentrated $\mathrm{HNO}_{3}$ for $14 \mathrm{~min}$, followed by venting the bombs. After addition of $2 \mathrm{~mL}$ of $\mathrm{H}_{2} \mathrm{O}_{2}$ (Merck, Darmstadt, Germany), samples were microwaved again and thereafter the clear digest was transferred to Teflon tubes and evaporated to dryness under filtered $\mathrm{N}_{2}$.

Samples were redissolved in $0.1 \mathrm{M} \mathrm{HNO}_{3}$ before GFAAS measurement. Pyrolytically coated graphite tubes (Varian Tech- 
tron) were used. The furnace program included charring at $600^{\circ} \mathrm{C}$ and atomization at $2300^{\circ} \mathrm{C}$. Measurements were done in the peak mode, using deuterium background correction. Standard addition was not used because comparison of measurements with external calibration against standards in $0.1 \mathrm{M} \mathrm{HNO}_{3}$ and standard addition gave the same results. Recovery of added $\mathrm{Fe}$ was found to be $99 \%$. Analysis of blank samples showed reproducible results; a mean blank value of $22 \pm 5 \mathrm{ng}(n=9)$ was found. The detection limit for $\mathrm{Fe}$ was $0.27 \mathrm{nmol}$ (15 ng), calculated from 3 times SD of the blank value. Precision for triplicate analysis of milk samples was $4.5 \%$. A reference material (Skim Milk Powder, BCR 63, Community Bureau of References, Brussels, Belgium) was analyzed together with the milk samples. A value of 0.031 $\pm 0.0007 \mu \mathrm{mol} / \mathrm{g}(1.71 \pm 0.04 \mu \mathrm{g} / \mathrm{g})(n=9)$ was found. This is somewhat lower than the certified value $0.037 \pm 0.004 \mu \mathrm{mol} / \mathrm{g}$ $(2.06 \pm 0.25 \mu \mathrm{g} / \mathrm{g})$.

Only Teflon and polyethylene containers were used and all material was rigorously cleaned by soaking in $1 \mathrm{M} \mathrm{HNO}_{3}$ for 24 $\mathrm{h}$, followed by rinsing with ultrapure water (18 M $\Omega$, Millipore AG, Zürich, Switzerland). Nitric acid was cleaned by sub-boiling distillation whereas $\mathrm{H}_{2} \mathrm{O}_{2}$ was suprapure quality. Sample preparation was done in a laminar flow hood. After each digestion, Teflon vessels were cleaned twice with $20 \mathrm{~mL}$ of $7 \mathrm{M} \mathrm{HNO}_{3}$ by heating in the microwave oven for $10 \mathrm{~min}$. A blank value was measured from each vessel before reusing it.

Stable Isotopes. Stable isotopes of $\mathrm{Fe}\left({ }^{57} \mathrm{Fe}\right.$ and $\left.{ }^{58} \mathrm{Fe}\right)$ were purchased from Medgenix Diagnostics (Düsseldorf, Germany) as metallic Fe. The isotopic composition of the ${ }^{58} \mathrm{Fe}$ label was $93.31 \%{ }^{58} \mathrm{Fe}, 6.54 \%{ }^{57} \mathrm{Fe}$, and $0.154 \%{ }^{56} \mathrm{Fe}$ and $95.30 \%{ }^{57} \mathrm{Fe}$, $2.37 \%{ }^{58} \mathrm{Fe}$, and $2.34 \%{ }^{56} \mathrm{Fe}$ for the ${ }^{57} \mathrm{Fe}$ label. The metallic ${ }^{58} \mathrm{Fe}$ was dissolved in sulfuric acid to obtain ${ }^{58} \mathrm{FeSO}_{4}$. The ${ }^{57} \mathrm{FeSO}_{4}$ was prepared according to the method described earlier (29). Solutions containing 12.2 and $6.52 \mathrm{mmol}$ of total $\mathrm{Fe} / \mathrm{L}$ were made up for ${ }^{57} \mathrm{Fe}$ and ${ }^{58} \mathrm{Fe}$, respectively. Ascorbic acid (11.8 $\mathrm{mmol} / \mathrm{L}$ ) was added to the ${ }^{57} \mathrm{Fe}$ solution whereas no addition of ascorbic acid was made to the ${ }^{58} \mathrm{FeSO}_{4}$ solution. Portions equivalent to one reference dose $\left(50.2 \mu \mathrm{mol} ; 2.86 \mathrm{mg}{ }^{57} \mathrm{Fe}\right)$ or enough ${ }^{58} \mathrm{Fe}$ to label the two batches of milk per infant $(18.3 \mu \mathrm{mol} ; 1.06$ $\mathrm{mg}{ }^{58} \mathrm{Fe}$ in $3 \mathrm{~mL}$ of solution) were filled into sterile glass ampules, purged with nitrogen, and sealed. The ampules were stored at $4^{\circ} \mathrm{C}$ in the dark until used.

Labeling of Milk Samples with Stable Isotopes. As part of the Fe absorption technique, a total amount of $8.6 \mu \mathrm{mol}(0.5 \mathrm{mg})$ of ${ }^{58} \mathrm{Fe}$ had to be added to each batch of milk followed by freezing until administered. Three preliminary studies were made to 1 ) determine the optimum time at which the added Fe has the same distribution in the milk as native $\mathrm{Fe}, 2$ ) to determine the effect of freezing on the distribution of added $\mathrm{Fe}$, and 3) to determine the distribution of added $\mathrm{Fe}$ in the whey fractions from breast milk and Lf-free breast milk.

Optimum time for equilibration. Two aliquots $(20 \mathrm{~mL})$ each of Lf-free breast milk and untreated breast milk were labeled with $11 \mathrm{kBq}$ of ${ }^{59} \mathrm{Fe}$ (NEN/Dupont, Wilmington, DE; sp act $2120 \mathrm{MBq} / \mathrm{mg}$ as ferric chloride). Also, $\mathrm{FeSO}_{4}$ (Fisher Scientific, Fairlawn, $\mathrm{NJ}$ ) was added in a quantity equivalent to $9.0 \mu \mathrm{mol}$ $(0.5 \mathrm{mg}) \mathrm{Fe} / \mathrm{L}$ to one sample $(20 \mathrm{~mL})$ each of Lf-free breast milk and breast milk and the milks were shaken gently at $4^{\circ} \mathrm{C}$. Aliquots $(5 \mathrm{~mL})$ were removed at 24,48 , and $72 \mathrm{~h}$. The distribution of the radioisotope in the lipid, whey, and pellet fractions was determined by gamma counting (Gamma 8500, Beckman Instruments Inc., Fullerton, CA) after ultracentrifugation at $242700 \times g$ for 30 min (Sorvall ultracentrifuge OTD65B, Dupont Instruments).

Effect of freezing on distribution of added Fe. Aliquots $(5 \mathrm{~mL})$ of untreated breast milk and Lf-free breast milk equilibrated for $24 \mathrm{~h}$ with added ${ }^{59} \mathrm{Fe}$ and $\mathrm{FeSO}_{4}$ (prepared as described above) were frozen at $-20^{\circ} \mathrm{C}$ for $1,2,3$, and 4 wk. At each time point, samples from the milks were thawed and the distribution of ${ }^{59} \mathrm{Fe}$ measured.

Distribution of $\mathrm{Fe}$ in the whey fractions. FPLC (Pharmacia
Fine Chemicals, Piscataway, NJ) was used to determine the distribution of the added $\mathrm{Fe}$ in the whey fractions from the above experiments. After ultrafiltration, whey fractions from breast milk and Lf-free breast milk were filtered $(0.2$ and $0.45 \mu \mathrm{m}$, Acrodisc syringe filters, Gelman Sciences, Ann Arbor, MI) and $1.0 \mathrm{~mL}$ was injected into the gel filtration column (Superose 12 , Pharmacia). The running buffer was $20 \mathrm{mM}$ ethanolamine with $0.3 \mathrm{M} \mathrm{NaCl}$, degassed and filtered through $0.22 \mu \mathrm{m}$ filters (Millipore Corp., Bedford, MA). The flow rate was $1 \mathrm{~mL} / \mathrm{min}$ and peaks were monitored at $280 \mathrm{~nm}$. Eluted fractions were measured for their content of radioactivity by gamma counting and pooled fractions (containing the major part of the ${ }^{59} \mathrm{Fe}$ ) were further evaluated by SDS-PAGGE (10-20\% gels). Citrate (Sigma, St. Louis, MO) prepared as $50 \mathrm{mM}$ solutions with $\mathrm{pH} 2.38$ and 7.00 , respectively, was also separated by FPLC (after addition of 11 $\mathrm{kBq}{ }^{59} \mathrm{Fe}$ ) and eluted fractions were measured by gamma counting.

Labeling of Milk for the Fe Absorption Study. A preweighed ampule of ${ }^{58} \mathrm{Fe}$ was opened, the content divided into two equal parts using sterile syringes, and identical volumes of isotope solution were added to each batch of breast milk and $\mathrm{Lf}$-free breast milk. The two batches of milk for each infant were always labeled at the same time and with the same amount of added $\mathrm{Fe}$. Before addition of the isotope solution, the fat from each defatted milk fraction of the Lf-free breast milk was replaced.

The labeled milks were left at $4^{\circ} \mathrm{C}$ and gently stirred for $24 \mathrm{~h}$ to enable the added $\mathrm{Fe}$ to equilibrate with the native $\mathrm{Fe}$. Feeding portions were made by weighing labeled milk into sterile disposable bottles (Playtex Family Products Corp.) according to each mothers' estimate of amounts required for a single feed. The size of the portions varied according to the infant's age, but were in the range of 115 to $155 \mathrm{~g}$ per bottle. Each bottle was labeled with the infants' code and A or B for Lf-free breast milk and breast milk, respectively. The feeding portions were kept frozen until administered.

Administration of Labeled Milk. The infants were randomly assigned to be fed either Lf-free breast milk or breast milk during the first administration of labeled milk in the study. The individual bottles were thawed in warm tap water immediately before the infants were fed. Mothers were instructed not to use microwave ovens or excessively hot water for heating the milk. The study was carried out in the homes with either one of the parents or the regular baby-sitter feeding the infant. Most babies were fed by their parents and in case of having the baby-sitter feeding the labeled milk, special care was taken to make sure that this person was informed about the study protocol. No other food or fluid was allowed during the administrations of labeled milk. The administration started in the morning at the normal time of the first feed of the day and only labeled breast milk was given until all the labeled milk in each batch had been consumed (approximately $24 \mathrm{~h}$ ). The mothers were closely supervised as how to feed the milk, to keep records of feeding times, and to save all used bottles in the freezer to be weighed later. Preweighed bibs and disposable wipes were provided during the administrations to estimate losses during the feeds. The use of bibs and wipes was registered and all used material was kept frozen until thawed and weighed. The second batch of labeled milk was administered, under identical conditions, approximately 15 to 16 days after intake of the first batch.

Reference Dose. A reference dose consisting of $50.2 \mu \mathrm{mol}(2.86$ $\mathrm{mg}$ ) of ${ }^{57} \mathrm{Fe}$ (as $\mathrm{FeSO}_{4}$ ) was administered on the day after each administration of labeled milk. The reference dose was prepared immediately before each administration by opening a preweighed ampule, adding $0.62 \mathrm{mmol}(123 \mathrm{mg})$ of sodium ascorbate (Lascorbic acid sodium salt, A-7631 Lot $90 \mathrm{H} 0667$, Sigma) and 630 $\mathrm{mg}$ of sucrose (cane sugar) and mixing the contents by drawing portions of the solution into a sterile syringe with an 18-gauge needle and returning it to the ampule several times. The solution $(5 \mathrm{~mL})$ was weighed into two sterile $3-\mathrm{mL}$ syringes that were used to administer the dose directly into the infant's mouth. 
Syringes were weighed before and after administrations to calculate the dose given to each infant. Preweighed bibs and wipes were used to collected rejected solution.

Blood Samples. Venous blood samples (total volume 2-3 mL) were drawn at local clinical laboratories before each administration of labeled milk and $14 \mathrm{~d}$ after intake of each reference dose. Whole blood was used to determine the isotope ratios ${ }^{57} \mathrm{Fe} /{ }^{56} \mathrm{Fe}$ and ${ }^{58} \mathrm{Fe} /{ }^{56} \mathrm{Fe}$, whereas serum samples were obtained for analysis of serum Fe, total Fe binding capacity, and ferritin. Hemoglobin was analyzed at the clinical laboratories using routine technique. Serum $\mathrm{Fe}$ and total $\mathrm{Fe}$ binding capacity were analyzed by a colorimetric method (Sigma kit no. 565-A, Sigma Diagnostics), whereas ferritin was determined by an enzyme immunoassay (Medix Biotech kit MB-1053, Medix Biotech Inc., Foster City, CA).

Analysis of Stable Isotopes in Blood Samples. One baseline and two enriched blood samples were analyzed per infant for their isotopic composition. The method used for sample preparation and analysis has been described in detail elsewhere (29). Isotope ratios were measured by thermal ionization mass spectrometry (Finnigan MAT model THQ, Bremen, Germany), after loading samples onto rhenium filaments.

Iron absorption was calculated based on the enrichment of ${ }^{58} \mathrm{Fe}$ and ${ }^{57} \mathrm{Fe}$ in red blood cells measured $14 \mathrm{~d}$ after administration. Corrections for enriched baseline values were made when calculating Fe absorption from the second labeled test meal as well as for the second reference dose. Fe absorption was calculated based on an assumed blood volume $(65 \mathrm{~mL} / \mathrm{kg})$ and incorporation of $90 \%$ of absorbed Fe into red blood cells (29). Percentage absorption values were converted to logarithms for statistical analysis and the results were reconverted to the antilogarithms to recover the original units (30).

Statistics. Paired $t$ test was used when comparing Fe absorption from breast milk to Lf-free breast milk as well as to compare Fe absorption from the two reference doses.

\section{RESULTS}

Labeling of Milk Samples with Stable Isotopes. Optimum equilibration time. The distribution of added ${ }^{59} \mathrm{Fe}$ in milk samples (breast milk and Lf-free breast milk) after different equilibration times showed only minor differences between samples with native $\mathrm{Fe}$ present as compared to milk with added $\mathrm{FeSO}_{4}$ (Table 1). With increasing labeling time, ${ }^{59} \mathrm{Fe}$ moved from the whey fraction into the fat layer. For practical and hygienic reasons, a labeling time of $24 \mathrm{~h}$ was chosen when preparing labeled milk for the Fe absorption study.

Effect of freezing. Information from the study of the effect of freezing on distribution of added $\mathrm{Fe}$ also shows a tendency toward

Table 1. Distribution of ${ }^{59} \mathrm{Fe}$ in fractions of breast milk and Lf-free breast milk with and without added $\mathrm{FeSO}_{4}$ (9 $\mathrm{\mu mol} / \mathrm{L} ; 0.5 \mathrm{mg} \mathrm{Fe} / \mathrm{L})$

\begin{tabular}{lcccc}
\hline & $\begin{array}{c}\text { Labeling } \\
\text { time } \\
\text { (h) }\end{array}$ & \multicolumn{3}{c}{ Distribution of ${ }^{59} \mathrm{Fe}$} \\
\cline { 2 - 5 } & 24 & 89 & 4 & 6 \\
Whey & Pellet & $\begin{array}{c}\text { Fat } \\
(\%)\end{array}$ & $(\%)$ & $(\%)$ \\
\hline Breast milk & 48 & 86 & 5 & 9 \\
Breast milk + Fe & 72 & 83 & 4 & 13 \\
& 24 & 89 & 5 & 6 \\
Lf-free breast milk & 48 & 86 & 4 & 10 \\
& 72 & 80 & 4 & 16 \\
& 24 & 87 & 5 & 8 \\
Lf-free breast milk + Fe & 48 & 83 & 5 & 12 \\
& 72 & 79 & 5 & 16 \\
& 24 & 88 & 4 & 8 \\
& 48 & 86 & 5 & 9 \\
& 72 & 83 & 4 & 13 \\
\hline
\end{tabular}

increased amounts of ${ }^{59} \mathrm{Fe}$ moving from the whey compartment into the fat fraction during storage at $-20^{\circ} \mathrm{C}$ (Fig. 2). However, the differences in the distribution of added $\mathrm{Fe}$ isotope were small. To avoid a systematic error in distribution of added $\mathrm{Fe}$ isotope during the Fe absorption study, the administration of labeled milk was randomized.

Distribution of $\mathrm{Fe}$ in whey. When whey samples from breast milk and Lf-free breast milk were separated by FPLC the mean fraction of ${ }^{59} \mathrm{Fe}$ that coeluted with citrate was 32 and $52 \%$, respectively.

Fe absorption study. Data on sex, age, body weight, and indices of Fe status for each infant at the time of the first blood sample are given in Table 2. All infants were judged to have normal Fe status, except for one slightly low $\mathrm{Hb}$ (baby B) and one ferritin value $<12 \mu \mathrm{g} / \mathrm{L}$ (baby $\mathrm{G}$ ). Concentrations of $\mathrm{Fe}, \mathrm{Lf}$, and total protein in the milk samples from each mother (breast milk and Lf-free breast milk, respectively) are shown in Table 3 . The removal of $L f$ from each batch of $L f$-free breast milk was checked by SDS-PAGGE and Western blots. In each case only traces of Lf remained and the results from the ELISA assay confirmed that $>97 \%$ of the total Lf was removed from all milk samples (Table 3). In most samples, the remaining $\mathrm{Lf}$ content was $<1 \%$ of the value in untreated milk. Mean $( \pm S D)$ concentration of $\mathrm{Lf}$ was $1.8 \pm 0.4 \mathrm{~g} / \mathrm{L}$ in breast milk as compared to $0.014 \pm 0.012$ $\mathrm{g} / \mathrm{L}$ in Lf-free breast milk, demonstrating a mean $( \pm \mathrm{SD})$ decrease of $99 \pm 0.7 \%$. The total protein content decreased from $9 \pm 2 \mathrm{~g} /$ $\mathrm{L}$ to $7 \pm 2 \mathrm{~g} / \mathrm{L}$ after removal of $\mathrm{Lf}$. This decrease is equivalent to a $25 \pm 8 \%$ reduction. $L f$ represented $21 \pm 7 \%$ of total protein in the untreated breast milk. The Fe concentration in breast milk was $2.5 \pm 0.5 \mu \mathrm{mol} / \mathrm{L}(140 \pm 30 \mu \mathrm{g} / \mathrm{L}$ ) (infants A-G). The Fe concentration decreased to $1.6 \pm 0.5 \mu \mathrm{mol} / \mathrm{L}(90 \pm 30 \mu \mathrm{g} / \mathrm{L})$ in Lf-free breast milk, corresponding to a $37 \pm 7 \%$ reduction (infants A-G)

The amount of labeled milk ingested as well as intake of ${ }^{58} \mathrm{Fe}$ for each child is given in Table 4 . Total volume of labeled milk varied between 700 and $1000 \mathrm{~g} /$ administration, but the volume was held constant between administrations for each infant. The intakes given in Table 4 demonstrate a consumption of $93 \pm 6$ and $94 \pm 3 \%$ of the total volume labeled milk for breast milk and Lf-free breast milk, respectively. All infants, with the exception of baby $\mathrm{H}$, received a dose of $8.6 \mu \mathrm{mol} / \mathrm{L}(0.5 \mathrm{mg}){ }^{58} \mathrm{Fe}$ per administration. Baby $\mathrm{H}$ received double the dose at both administrations.

Absorption of $\mathrm{Fe}$ was found to be significantly $(p<0.05)$ higher when Lf-free breast milk was fed, as compared to breast milk. The geometric mean absorption (range) was 11.8 (3.4$37.4) \%$ for breast milk and $19.8(8.4-72.8) \%$ when Lf-free breast milk was fed (Table 5). Absorption of Fe from the reference dose was 24.3 (14.8-47.7)\% when given after intake of breast milk and $22.4(11.4-47.3) \%$ when given after intake of Lf-free breast milk (Table 5). These values were not significantly different.

\section{DISCUSSION}

Our study does not show any enhancing effect of $\mathbf{L f}$ on $\mathbf{F e}$ absorption from breast milk in this age group of breast-fed infants. On the contrary, an inhibitory effect of Lf was demonstrated because Fe absorption was significantly lower when Lf was present as compared to $\mathrm{Lf}$-free breast milk. These results are in agreement with some earlier studies in which an inhibitory effect of $\mathrm{Lf}$ on Fe-absorption has been demonstrated after introduction of purified human Lf into the duodenum of adult subjects (31) and after addition of human Lf to "simulated human milk" at a concentration similar to that of breast milk (9). It is interesting to note, however, that in the youngest infant studied, Fe absorption was higher from human milk than from Lf-free breast milk. The hypothesis raised earlier by Brock (32), that the biological role of $\mathrm{Lf}$ changes from early to late infancy may therefore still be valid.

The results from our study also showed a relatively low frac- 


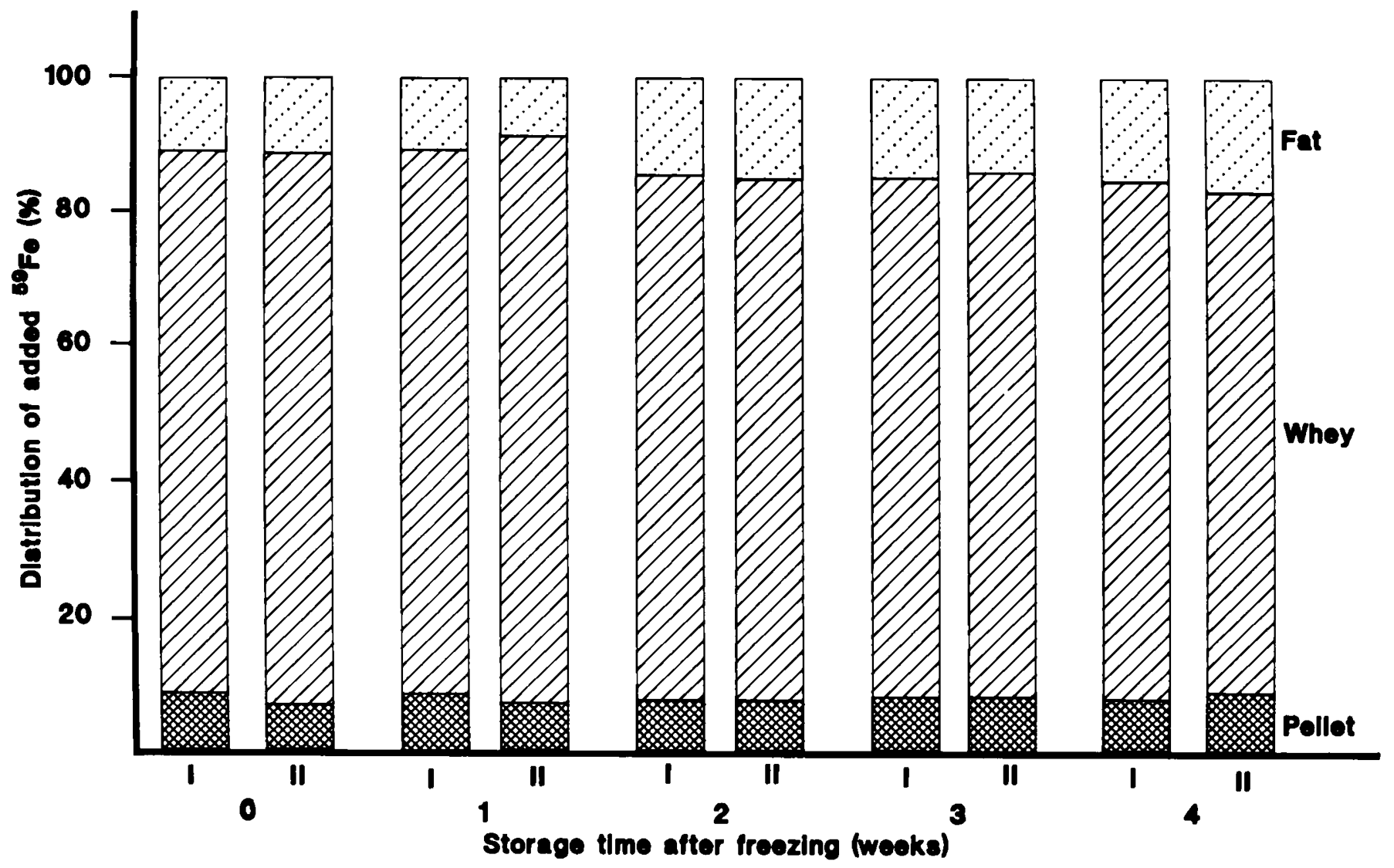

Fig. 2. Distribution of ${ }^{59} \mathrm{Fe}$ in fractions of I, breast milk and II, Lf-free breast milk. All samples contained added iron $(9 \mu \mathrm{mol} / \mathrm{L} ; 0.5 \mathrm{mg} / \mathrm{L})$.

Table 2. Infant sex, age, body weight $(B W)$, hemoglobin $(\mathrm{Hb})$, serum iron $(\mathrm{S}-\mathrm{Fe})$, total iron binding capacity $(T I B C)$ and ferritin at the start of the study*

\begin{tabular}{ccccccc}
\hline $\begin{array}{c}\text { Infant } \\
(\text { sex })\end{array}$ & $\begin{array}{c}\text { Age } \\
(\mathrm{mo})\end{array}$ & \multicolumn{1}{c}{$\begin{array}{c}\text { BW } \\
(\mathrm{g})\end{array}$} & $\begin{array}{c}\mathrm{Hb} \\
(\mathrm{g} / \mathrm{L})\end{array}$ & $\begin{array}{c}\mathrm{S}-\mathrm{Fe} \\
(\mu \mathrm{g} / \mathrm{L})\end{array}$ & $\begin{array}{c}\text { TIBC } \\
(\mu \mathrm{g} / \mathrm{L})\end{array}$ & $\begin{array}{c}\text { Ferritin } \\
(\mu \mathrm{g} / \mathrm{L})\end{array}$ \\
\hline A (F) & 4 & 5995 & 118 & 318 & 3279 & 108.1 \\
B (M) & 2 & 7600 & 99 & 329 & 2688 & 334.5 \\
C (M) & 5 & 8052 & 122 & 600 & 3177 & 16.7 \\
D (F) & 3 & 6180 & 118 & 388 & 1683 & 365.2 \\
E (F) & 6 & 7550 & 110 & 400 & 2708 & 88.3 \\
F (M) & 4 & 7270 & 124 & 235 & 2735 & 53.0 \\
G (F) & 10 & 10380 & 119 & 376 & 4505 & 7.5 \\
H (M) & 7 & 9736 & 119 & 518 & 3082 & 79.1 \\
\hline
\end{tabular}

* To convert micrograms per liter to micromoles per liter, divide by 55.85 (S-Fe and TIBC) and by 450000 (ferritin).

tional Fe absorption from breast milk, with a mean value of $11.8 \%$. Earlier studies in infants have reported Fe absorption (or retention) from breast milk to be in the range of 49 to $81 \%$ (57). Studies in adult subjects have also demonstrated relatively high fractional $\mathrm{Fe}$ absorption from human milk; mean values were $21(8), 15(9)$, and $48 \%$ (10). However, the study design used in the previous studies in infants make the interpretation of the results somewhat difficult. In the study by Saarinen et al. (7) the radioisotope $\left({ }^{59} \mathrm{Fe}\right)$ was administered as a solution into the mouth of the infants during a feed of breast milk. Fe absorption from human milk was reported to be $48.8 \pm 7.9 \%$. In the second part of the same study, Fe absorption from an isotope solution was measured, without any food present in infants usually fed either human milk or cow's milk formula. Fe absorption was $38.1 \pm 6.5 \%$ when measured in breast-fed infants and $19.5 \pm 5.2 \%$ in formula-fed babies. The results in the first
Table 3. Content of total protein, $L f$ and $\mathrm{Fe}$ in aliquots of breast milk and Lf-free breast milk (before addition of ${ }^{58} \mathrm{Fe}$ )*

\begin{tabular}{|c|c|c|c|c|c|c|}
\hline \multirow[b]{2}{*}{ Infant } & \multicolumn{3}{|c|}{ Breast milk } & \multicolumn{3}{|c|}{ Lf-free breast milk } \\
\hline & $\begin{array}{c}\text { Total } \\
\text { protein } \\
(\mathrm{g})\end{array}$ & $\begin{array}{l}\text { Lf } \\
(\mathrm{g})\end{array}$ & $\begin{array}{c}\mathrm{Fe} \\
(\mu \mathrm{g})\end{array}$ & $\begin{array}{c}\text { Total } \\
\text { protein } \\
(\mathrm{g})\end{array}$ & $\begin{array}{r}\text { Lf } \\
(\mathrm{g})\end{array}$ & $\begin{array}{c}\mathrm{Fe} \\
(\mu \mathrm{g})\end{array}$ \\
\hline A & 11 & 2.3 & 160 & 8 & 0.012 & 88 \\
\hline B & 12 & 1.2 & 170 & 9 & 0.006 & 130 \\
\hline C & 10 & 1.6 & 130 & 6 & 0.006 & 84 \\
\hline D & 7 & 1.8 & 110 & 5 & 0.007 & 65 \\
\hline E & 8 & 2.4 & 130 & 6 & 0.016 & 82 \\
\hline F & 11 & 1.7 & 170 & 9 & 0.006 & 99 \\
\hline G & 8 & 1.6 & 99 & 6 & 0.041 & 63 \\
\hline $\mathrm{H}$ & 7 & 2.0 & $1400 \dagger$ & 6 & 0.021 & $1420 \dagger$ \\
\hline
\end{tabular}

* All values are given per liter. To convert grams per liter to moles per liter, divide by 80000 (lactoferrin). To convert micrograms of Fe per liter to micromoles of Fe per liter, divide by 55.85 .

+ Analysis after addition of ${ }^{58} \mathrm{Fe}$.

study could have been influenced by the lack of equilibration between the isotope and the native Fe. In the second part of the study, the Fe absorption values measured without any food may more reflect $\mathrm{Fe}$ status of the infants, and not $\mathrm{Fe}$ absorption from human milk or formula. Furthermore, the data reported by Saarinen (5) and Garry (6) on estimated Fe absorption from breast milk was generated using an indirect method based on calculated changes in total body Fe over a period of time. This methodology is based on measured changes of Fe status ( $\mathrm{Hb}$ and ferritin) and estimated intakes of $\mathrm{Fe}$ and includes certain potential errors (e.g. the Fe content in human milk was assumed to be $17.9 \mu \mathrm{mol} / \mathrm{L} ; 1 \mathrm{mg} / \mathrm{L}$ ). Finally, the absorption study by Hallberg 
Table 4. Intake of labeled milk per administration and intake of ${ }^{88}$ Fe from breast milk and Lffree breast milk, respectively*

\begin{tabular}{cccccc}
\hline & \multicolumn{2}{c}{ Breast milk } & & \multicolumn{2}{c}{ Lf-free breast milk } \\
\cline { 2 - 3 } \cline { 5 - 6 } Infant & $\begin{array}{c}\text { Milk intake } \\
(\mathrm{g})\end{array}$ & $\begin{array}{c}{ }^{58} \mathrm{Fe} \text { intake } \\
(\mu \mathrm{g})\end{array}$ & & $\begin{array}{c}\text { Milk intake } \\
(\mathrm{g})\end{array}$ & $\begin{array}{c}{ }^{58} \mathrm{Fe} \text { intake } \\
(\mu \mathrm{g})\end{array}$ \\
\hline A & 924 & 451 & & 985 & 484 \\
B & 969 & 512 & & 939 & 507 \\
C & 893 & 528 & & 835 & 492 \\
D & 587 & 452 & & 676 & 522 \\
E & 981 & 535 & & 978 & 530 \\
F & 713 & 440 & & 765 & 478 \\
G & 967 & 511 & & 915 & 488 \\
H & 946 & 1005 & & 882 & 943 \\
\hline
\end{tabular}

* To convert micrograms of ${ }^{58} \mathrm{Fe}$ to micromoles, divide by 58 .

Table 5. Fractional Fe absorption from breast milk, Lf-free breast milk, and the reference doses, respectively

\begin{tabular}{lrccc}
\hline & \multicolumn{4}{c}{ Fe absorption (\%) } \\
\cline { 2 - 5 } & $\begin{array}{c}\text { Breast } \\
\text { milk }\end{array}$ & $\begin{array}{c}\text { Reference } \\
\text { dose }\end{array}$ & $\begin{array}{c}\text { Lf-free breast } \\
\text { milk }\end{array}$ & $\begin{array}{c}\text { Reference } \\
\text { dose }\end{array}$ \\
\hline A & 5.6 & 22.0 & 10.5 & 13.4 \\
B & 19.5 & 21.1 & 10.0 & 44.5 \\
C & 26.9 & 47.7 & 38.0 & 47.3 \\
D & 3.4 & 23.3 & 8.4 & 11.4 \\
E & 15.8 & 26.9 & 23.5 & 23.0 \\
F & 4.4 & 20.0 & 12.8 & 15.7 \\
G & 37.4 & 29.9 & 72.8 & 37.9 \\
H & 14.5 & 14.8 & 31.5 & 14.2 \\
Geometric mean & 11.8 & 24.3 & 19.8 & 22.4 \\
+1 SD & 28.6 & 34.3 & 42.7 & 39.9 \\
-1 SD & 4.9 & 17.3 & 9.2 & 12.5 \\
\hline
\end{tabular}

et al. (10) is not likely to take into account any effect of Lf as this protein is likely to be completely digested in adults.

An important feature of our study was that we measured Fe absorption from a relatively large quantity of labeled human milk $(700-1000 \mathrm{~g})$, administered in several feeds over a period of approximately $24 \mathrm{~h}$, whereas earlier studies have used smaller test meals, i.e. single meals (7-10). The effect of the meal size on $\mathrm{Fe}$ absorption has been demonstrated earlier in rhesus monkeys who absorbed a larger fraction of $\mathrm{Fe}$ when the size of the test meal was reduced (25). The value for $\mathrm{Fe}$ absorption from human milk obtained in our study thus probably reflects more closely $\mathrm{Fe}$ absorption under normal feeding conditions. The relatively low fractional $\mathrm{Fe}$-absorption found by us might reflect the low need for Fe early in life when the infant.can still utilize Fe stores accrued during fetal life. Lf levels are highest in milk of humans and guinea pigs, both of whose young grow notably slower than those of other species of comparable size and the need for exogenous $\mathrm{Fe}$ will therefore be lower (32). Thus, Lf may still have an important role in controlling Fe absorption in the very young child. Based on our data (Table 5) fractional Fe absorption seems to increase with age because the older infants absorbed a larger fraction of the Fe present in human milk than the younger infants. However, the number of infants studied is too small to draw any conclusions on the effect of age on $\mathrm{Fe}$ absorption. In addition, $\mathrm{Fe}$ status also varied with age, i.e. the oldest infant had very low storage $\mathrm{Fe}$ (ferritin) and the youngest infant had higher stores.

When discussing the results from our study, several points need to be addressed in relation to the data generated. The removal of $\mathrm{Lf}$, the study design and the stable isotope methodology including the labeling technique all have to be considered as potentially influencing the results. Lf was removed by using heparin-Sepharose which binds Lf specifically (33). This method was considered as the most suitable technique to remove $\mathrm{Lf}$ without introducing any other major modifications of the milk. Heat treatment of human milk does inactivate most of the Lf but also leads to modifications of the milk by denaturation of other proteins, e.g. immunoglobulins (34). A study design including paired comparisons is essential when evaluating the influence of dietary components on Fe absorption in infants (35). In the present study we included, apart from the paired comparison, administration of a reference dose as close in time as possible to each intake of labeled milk. Fe status in itself affects Fe absorption and we wanted to make sure that no such changes occurred during the time span of the study. No significant differences were found between the two administrations of reference doses, providing support for the notion that Fe status (or Fe absorption) did not change during this time.

Because fractional $\mathrm{Fe}$ absorption is generally low, the chemical balance technique is not a useful approach. Due to the risk involved, radioisotopes are often not permitted in studies of infants. A better alternative, especially in infants, is to use a stable isotope technique as this methodology does not impose any radiation risk for the participating subjects. Stable isotope techniques for studies of $\mathrm{Fe}$ absorption in infants have previously been developed by Fomon $e t$ al. (35) and by Kastenmayer $e t$ al. (29). Their main disadvantage is that unlike the radioisotope technique, a significant quantity of $\mathrm{Fe}$ is added to the food as a label. It is especially important in studies where the test meals contain very small amounts of native $\mathrm{Fe}, e . g$. human milk as addition of the isotope contributes significantly to the total $\mathrm{Fe}$ content in the diet fed. In the present study we kept the amount of added $\mathrm{Fe}$ as low as possible by choosing the $\mathrm{Fe}$ isotope with the lowest natural abundance $\left({ }^{58} \mathrm{Fe}\right)$, added in a highly enriched form. However, the increase of the total $\mathrm{Fe}$ content in the administered amounts of milk was in the range of 4- to 13-fold depending on the Fe concentration of milk from different mothers. The increase in $\mathrm{Fe}$ content was highest for baby $\mathrm{H}$ who received twice the dose of ${ }^{58} \mathrm{Fe}$ compared to the other infants. A decreased fractional absorption of $\mathrm{Fe}$ has been demonstrated with increasing dosage in studies of adult subjects (36). Very little information is available on the effect of the Fe content of the meal on $\mathrm{Fe}$ absorption in infants. However, in adults it has been demonstrated that $\mathrm{Fe}$ in infant formula was absorbed to approximately $3 \%$ whether $\mathrm{Fe}$ was added as fortification $\mathrm{Fe}(215 \mu \mathrm{mol} /$ $\mathrm{L} ; 12 \mathrm{mg} / \mathrm{L}$ ), or present only as native $\mathrm{Fe}(9)$. Thus, the effect of the increased content of $\mathrm{Fe}$ in the present study on the absorption of $\mathrm{Fe}$ from breast milk would not be expected to have a major impact on the results. In any case, the amount of added Fe was identical in the two test meals, and could therefore not explain the observed difference in Fe absorption between breast milk with and without $\mathrm{Lf}$.

An important aspect when evaluating results from Fe absorption studies is the labeling technique. Intrinsic labeling, where the isotope is incorporated in vivo as an integral part of native $\mathrm{Fe}$ in the test meal is theoretically the most appropriate way of labeling test meals. However, this is a very tedious procedure, which in our case would have included several injections of ${ }^{58} \mathrm{Fe}$ to the lactating mothers and collection of large milk volumes due to the expected very low enrichment of ${ }^{59} \mathrm{Fe}$ in the milk (37). In our study, we chose to use an extrinsic labeling technique, allowing a relatively long period of equilibration $(24 \mathrm{~h})$ to ensure distribution of the added ${ }^{58} \mathrm{Fe}$ equivalent to the distribution of native $\mathrm{Fe}$ in human milk. A labeling time consisting of $24 \mathrm{~h}$ was chosen, based on preliminary experiments as well as on practical considerations. This time period was considered as the maximum time for keeping human milk at $4^{\circ} \mathrm{C}$ when labeling the milk. In an earlier study (25), equilibration times up to $72 \mathrm{~h}$ were demonstrated to be needed when labeling human milk with ${ }^{59} \mathrm{Fe}$. However, in the present study we found only minor differences in the distribution of ${ }^{59} \mathrm{Fe}$ among different milk fractions when using labeling times between 24 and $72 \mathrm{~h}$. Furthermore, no major difference was observed in the distribution of ${ }^{59} \mathrm{Fe}$ in 
separate fractions of milk with and without Lf, either directly after labeling or after storage at $-20^{\circ} \mathrm{C}$ for up to $4 \mathrm{wk}$. Thus, the labeling technique chosen would not be expected to contribute to the difference observed in Fe absorption between breast milk and Lf-free breast milk.

Another aspect related to the labeling technique when using stable isotopes is the possible effect on Fe absorption that could be associated with changes in affinity of Lf to the receptor. The affinity of apo-Lf to the receptor is somewhat lower than that of mono- or diferric Lf (22). Addition of Fe to human milk would lead to increased saturation of Lf, but not to a lower binding capacity to the receptor. The lower Fe absorption observed from the breast milk (containing Lf and added Fe) could therefore not be explained by lower affinity to the receptor. Human milk Lf is saturated with $\mathrm{Fe}$ to a low degree, only 3 to $5 \%$ of its capacity is used (38), binding approximately $30 \%$ of the total Fe (13). Low molecular weight ligands such as citrate are present in human milk in concentrations considerably higher than that of $\mathrm{Lf}$. Equilibrium of the binding of $\mathrm{Fe}$ between citrate and $\mathrm{Lf}$ is therefore pushed toward the former ligand in human milk with normal composition (13) and likely even more so when $\mathrm{Lf}$ is removed. This was confirmed in the present study.

Recently, a study of Fe absorption in piglets demonstrated that the extrinsic tag methodology is not valid for studies of sow's milk (37). Extrinsic and intrinsic labeling of milk showed different distribution of the isotope between the fractions of fat, whey, and casein. The intrinsic label was mainly incorporated into fat, whereas extrinsically added isotope bound to casein. Fe retention measured in piglets was significantly higher from intrinsically labeled milk. However, sow's milk has a different composition as compared to human milk, e.g. considerably higher casein content and because casein is poorly digested by the young piglet this might explain the low $\mathrm{Fe}$ absorption from extrinsically labeled milk. No studies have been done to evaluate extrinsic versus intrinsic labeling in studies of Fe absorption from human milk due to the difficulties involved in achieving adequate isotope enrichment in human milk.

The physiological role of $\mathrm{Lf}$ in breast milk remains unclear. In this study, we obtained no support for an enhancing effect of Lf on Fe absorption in infants 3 to 10 mo old. It is still possible that such a role may exist during early neonatal life. It is also possible that $\mathrm{Lf}$ may bind to the mucosa and exert an indirect effect on Fe absorption, for example by enhancing mucosal proliferation. $\mathrm{Lf}$ removal during a short period of time may then have no immediate effect on Fe retention. In addition, we know little about the regulation of Fe uptake and transfer across the mucosal cell. The existence of a highly specific receptor on the brush border membrane of the human infant intestine (18) may facilitate cellular uptake of $\mathrm{Lf}$ and $\mathrm{Fe}$. This may in turn trigger intracellular events involved in regulation of Fe metabolism. It is also possible that the receptor is present to bind Lf and that any subsequent events are unrelated to $\mathrm{Fe}$ and its retention. Further studies at a cellular and molecular level are needed to answer some of these questions.

In conclusion, the mean $\mathrm{Fe}$ absorption from human milk was found to be relatively low, $11.8 \%$, when studied in breast-fed infants. The absorption of Fe increased significantly when Lf was removed from the milk, resulting in a mean Fe absorption of $19.8 \%$. The results from this study therefore do not support a role for Lf in increasing the $\mathrm{Fe}$ absorption from human milk.

Acknowledgment. The authors thank all mothers participating in the study for their cooperation.

\section{REFERENCES}

1. Siimes MA, Vuori E, Kuitunen P 1979 Breast milk iron: a declining concentration during the course of lactation. Acta Paediatr Scand 68:29-31

2. Lönnerdal B 1984 Iron and breast milk. In: Stekel A (ed) Iron Nutrition in Infancy and Childhood. Nestlé Nutrition Workshop Series, Vol. 4, Raven Press, New York, pp 95-114
3. Saarinen UM 1978 Need for iron supplementation in infants on prolonged breast feeding. J Pediatr 93:177-180

4. Duncan B, Schifman RB, Corrigan JJ, Schaefer C 1985 Iron and the exclusively breast-fed infant from birth to six months. J Pediatr Gastroenterol Nutr 4:421-425

5. Saarinen UM, Siimes MA 1979 Iron absorption from breast milk, cow's milk, and iron-supplemented formula: an opportunistic use of changes in total body iron determined by hemoglobin, ferritin, and body weight in 132 infants. Pediatr Res 13:143-147

6. Garry PJ, Owen GM, Hooper EM, Gilbert BA 1981 Iron absorption from human milk and formula with and without iron supplementation. Pediatr Res 15:822-828

7. Saarinen UM, Siimes MA, Dallman PR 1977 Iron absorption in infants: high bioavailability of breast milk iron as indicated by the extrinsic tag method of iron absorption and by the concentration of serum ferritin. J Pediatr 91:36-39

8. McMillan JA, Landaw SA, Oski FA 1976 Iron sufficiency in breast-fed infants and the availability of iron from human milk. Pediatrics 58:686-691

9. McMillan JA, Oski FA, Lourie G, Tomarelli RM, Landaw SA 1977 Iron absorption from human milk, simulated human milk, and proprietary formulas. Pediatrics 60:896-900

10. Hallberg L, Rossander-Hulthén L, Brune M, Gleerup A 1992 Bioavailability in man of iron in human milk and cow's milk in relation to their calcium contents. Pediatr Res 31:524-527

11. Hurrell RF, Berrocal R, Lynch SR, Dassenko SA, Cook JD 1990 The influence of bovine milk proteins on iron absorption in man. In: Hercberg $S$, Galan $\mathrm{P}$, Dupin $\mathrm{H}$ (eds) Recent Knowledge on Iron and Folate Deficiencies in the World, Vol. 197. Colloque INSERM, Paris, pp 265-273

12. Hurrell RF, Lynch SR, Trinidad TP, Dassenko SA, Cook JD 1989 Iron absorption in humans as influenced by bovine milk proteins. Am $\mathrm{J}$ Clin Nutr 49:546-552

13. Lönnerdal B 1990 Iron in human milk and cow's milk: effects of binding ligands on bioavailability. In: Lönnerdal $B$ (ed) Iron Metabolism in Infants. CRC Press, Boca Raton, FL, pp 87-108

14. Prentice A, MacCarthy A, Stirling DM, Vasquez-Velasquez L, Ceesay SM 1989 Breast milk IgA and lactoferrin survival in the gastrointestinal tract: a study in rural Gambian children. Acta Paediatr Scand 78:505-512

15. Davidson LA, Lönnerdal B 1987 Persistence of human milk proteins in the breast-fed infant. Acta Paediatr Scand 76:733-740

16. Spik G, Brunet B, Mazurier-Dehaine C, Fontaine G, Montreuil J 1982 Characterization and properties of the human and bovine lactoferrins extracted from the feces of newborn infants. Acta Paediatr Scand 71:979-985

17. Cox TM, Mazurier J, Spik G, Montreuil J, Peters TJ 1979 Iron binding proteins and influx of iron across the duodenal brush border. Evidence for specific lactotransferrin receptors in the human intestine. Biochim Biophys Acta 588:120-128

18. Kawakami H, Lönnerdal B 1990 Isolation and function of a receptor for human lactoferrin in human fetal intestinal brush border membranes. Am J Physiol 261:G841-G846

19. Davidson LA, Lönnerdal B 1988 Specific binding of lactoferrin to brush border membranes: ontogeny and effect of glycan chain. Am J Physiol 254:G580G585

20. Hu W-L, Mazurier J, Sawatzki G, Montreuil J, Spik G 1988 Lactoferrin receptor of mouse small-intestinal brush border. Biochem J 249:435-441

21. Iyer S, Gislason J, Hutchens TW, Lönnerdal B 1993 Lactoferrin receptors in piglets small intestine: binding kinetics, specificity, ontogeny and regional distribution. J Nutr Biochem 4:528-533

22. Davidson LA, Lönnerdal B 1989 Fe-saturation and proteolysis of human lactoferrin: effect on brush-border receptor-mediated uptake of Fe and $\mathrm{Mn}$. Am J Physiol 257:G930-G934

23. Fransson GB, Thoren-Tolling K, Jones B, Hambraeus L, Lönnerdal B 1983 Absorption of lactoferrin iron in suckling pigs. Nutr Res 3:373-384

24. Fransson GB, Keen CL, Lönnerdal B 1983 Supplementation of milk with iron bound to lactoferrin using weanling mice. I. Effects of hematology and tissue iron. J Pediatr Gastroenterol Nutr 2:693-700

25. Davidson LA, Litov RE, Lönnerdal B 1990 Iron retention from lactoferrinsupplemented formulas in infant rhesus monkeys. Pediatr Res 27:176-180

26. Fairweather-Tait SJ, Balmer SE, Scott PH, Minski MJ 1987 Lactoferrin and iron absorption in newborn infants. Pediatr Res 22:651-654

27. Schulz-Lell G, Dörner K, Oldigs H-D, Sievers E, Schaub J 1991 Iron availability from an infant formula supplemented with bovine lactoferrin. Acta Paediatr Scand 80:155-158

28. Chierci R, Sawatzki G, Tamisari L, Volpato S, Vigi V 1992 Supplementation of an adapted formula with bovine lactoferrin. Acta Paediatr Scand 81:475479

29. Kastenmayer P, Davidsson L, Galan P, Cherouvrier F, Hercberg S, Hurrell RF 1993 A double stable isotope technique for measuring iron absorption in infants. Br J Nutr (in press)

30. Cook JD, Layrisse M, Finch CA 1969 The measurement of iron absorption. Blood 33:421-429

31. De Vet BJCM, van Gool J 1974 Lactoferrin and iron absorption in the small intestine. Acta Med Scand 196:393-402 
32. Brock JH 1980 Lactoferrin in human milk: its role in iron absorption and protection against enteric infection in the newborn infant. Arch Dis Child 55:417-421

33. Bläckberg $L$, Hernell $O 1980$ Isolation of lactoferrin from human whey by a single chromatographic step. FEBS Lett 109:180-184

34. Ford JE, Law BA, Marshall VME, Reiter B 1977 Influence of the heat treatment of human milk on some of its protective constituents. J Pediatr 90:29-35

35. Fomon SJ, Janghorbani M, Ting BTG, Ziegler EE, Rogers RR, Nelson SE,
Ostegaard LS, Edwards BB 1988 Erythrocyte incorporation of ingested 58iron by infants. Pediatr Res 24:20-24

36. Bothwell TH, Charlton RW, Cook JD, Finch CA 1979 Iron Metabolism in Man. Blackwell Scientific, Oxford, pp 256-283

37. Gislason J, Jones B, Lönnerdal B, Hambraeus L 1992 Iron absorption differs in piglets fed extrinsically and intrinsically 59Fe-labeled sow's milk. J Nutr 122:1287-1292

38. Fransson GB, Lönnerdal B 1980 Iron in human milk. J Pediatr 96:380-384

\section{Announcement}

\section{4th Congress of the European Society for Pediatric Neurosurgery}

The 14th Congress of the European Society for Pediatric Neurosurgery will be held in Lyon, France from September 21 to 23, 1994. For further information, contact Professor Claude Lapras, Hôpital Neurologique, 59 Boulevard Pinel, Lyon Cedex 03, France, phone (33) 723571 94, fax (33) 72357300. 